\title{
A Polymerase Chain Reaction Assay for the Detection of Xanthomonas campestris pv. musacearum in Banana
}

\author{
Melanie L. Lewis Ivey, Department of Plant Pathology, The Ohio State University, Ohio Agricultural Research and \\ Development Center, Wooster 44691; Geoffrey Tusiime, Makerere University, Kampala, Uganda; and Sally A. \\ Miller, Department of Plant Pathology, The Ohio State University, Ohio Agricultural Research and Development \\ Center
}

\begin{abstract}
Lewis Ivey, M. L., Tusiime, G., and Miller, S. A. 2010. A polymerase chain reaction assay for the detection of Xanthomonas campestris pv. musacearum in banana. Plant Dis. 94:109-114.

Polymerase chain reaction (PCR) primers (BXW-1 and BXW-3) for conventional PCR were developed from conserved sequences in the $h r p B$ operon of the hrp gene cluster from Xanthomonas campestris pv. musacearum, the causative agent of banana Xanthomonas wilt (BXW). All 50 strains of $X$. campestris pv. musacearum, isolated from Uganda, Rwanda, and Tanzania, produced a 214-bp amplicon when whole cells, bacterial ooze from infected tissue, and genomic DNA purified from bacterial ooze or infected tissue were used as template. The BXW primers also detected strains of $X$. axonopodis pv. vasculorum isolated from sugarcane and maize and strains of X. vasicola pv. holcicola isolated from sorghum. All of the strains of X. campestris pv. musacearum were clonal when compared using enterobacterial repetitive intergenic consensus PCR.
\end{abstract}

Banana Xanthomonas wilt (BXW), also known as banana bacterial wilt (BBW) (57), is a devastating disease of banana (Musa spp.) and enset (Ensete ventricosum) in many African countries, including Ethiopia (57,58), Democratic Republic of Congo (33,34), Uganda $(54,55)$, Rwanda (42), Tanzania (32), Kenya (31), and Burundi (49). The disease is caused by the bacterium Xanthomonas campestris pv. musacearum $(15,60)$, formerly known as $X$. musacearum (57) and proposed as $X$. vasicola pv. musacearum (3). The pathogen's rapid spread through East Africa has threatened the livelihood of millions of Africans who rely on banana fruit for food and export trade. Annual banana production in Africa is currently at about 603,000 metric tons, with approximately $4 \%$ of that being cultivated for export trade (19). BXW attacks all cultivars of banana (7), causing annual losses of over 500 million dollars across East and Central Africa (4). Once the disease is established in an area, total yield loss may occur (7). One of the first characteristic symptoms of the disease is the shriveling of the male flower bud, followed by yellowing and wilting of leaves and premature fruit ripening and discoloration. A sign of the disease is bacterial ooze from vascular tissue and fruit.

Corresponding author: S. A. Miller

E-mail: miller.769@osu.edu

Accepted for publication 21 September 2009.

doi:10.1094/PDIS-94-1-0109

(c) 2010 The American Phytopathological Society
There are currently no commercial chemicals, biocontrol agents, or resistant cultivars available to control the pathogen (7).

Many symptoms of BXW are similar to those of other bacterial and fungal wilts of banana, including Fusarium wilt (Fusarium oxysporum f. sp. cubense) and Moko/bugtok disease (Ralstonia solanacearum) (53). Currently, BXW is identified by isolation of bacteria from infected tissue followed by fatty acid and metabolic analyses (55). Although these methods are acceptable, they are generally only used once symptoms are visible. However, by the time the plant is showing visible symptoms, the BXW pathogen has established itself within the plant, and control and eradication become very difficult. In addition, latent infections in host tissue can result in widespread distribution of the pathogen through movement of infected planting material.

Polymerase chain reaction (PCR) with pathogen-specific primers has been used for the rapid identification of many phytopathogenic bacteria $(5,9,10,14,20,24,25$, 30,35-37,39,50). Variable spacer regions within the $16 \mathrm{~S}$ and $23 \mathrm{~S}$ ribosomal DNA (rDNA) genes have been used extensively as targets for the development of hybridization probes and PCR primers $(8,13,27$, 44,48). However, in some phytobacteria, such as Ralstonia spp. $(43,48,52)$ and Xanthomonas spp. (21), variability in the rDNA sequences is limited and alternative targets are needed. Primers targeting functional genes, such as $\operatorname{gyrB}(44)$, endogluconase (40), the coronatine (COR) biosynthetic gene cluster, the phaseolotoxin (tox) gene cluster $(5,10,11,41), f l i C(47)$, and the hrp gene cluster $(6,22,24,25,35,38,61,62)$, have a higher resolution than rDNA-based genes and are good candidates for speciesspecific primer development.

In Xanthomonas spp. and other phytopathogenic bacteria, hrp genes determine pathogenicity in hosts and hypersensitivity in resistant or nonhosts $(1,56)$ but are not found in nonpathogenic species of Xanthomonas $(25,28,51)$. Previous observations from this laboratory (unpublished) and from studies in Ontario, Canada (10) showed that $X$. campestris pv. vesicatoriaspecific primers (RST65/RST69) developed from the $h r p B$ gene (35) crossreacted with other pathovars of $X$. campestris, including $X$. campestris pv. musacearum strains from this study. Unexpected, however, was the amplification of a unique additional lower molecular weight band with the $X$. campestris pv. musacearum strains. This additional band was not previously observed in our laboratory and was not reported in the study by Cuppels et al (10). Based on these observations, we hypothesized that an $X$. campestris pv. musacearum-specific PCR assay could be developed to detect $X$. campestris pv. musacearum in host banana plants. Hence, the objective of this study was to design and evaluate a robust, sensitive PCR assay for the early detection of BXW.

\section{MATERIALS AND METHODS}

Bacterial strains and growth conditions. The bacterial strains used in this study are listed in Table 1. All strains were maintained on yeast dextrose calcium carbonate (YDC) medium or yeast extract peptone glucose (YPG) medium (Clavibacter and Xanthomonas spp.) (26,46), Pseudomonas F (PF) medium (Pseudomonas spp.) or nutrient broth yeast extract (NBY) agar medium (Ralstonia spp.) and stored long term in NBY broth containing $15 \%$ glycerol at $-80^{\circ} \mathrm{C}$.

Isolation of $X$. campestris pv. musacearum from infected plant tissue. Bacteria were isolated from pseudostems of symptomatic banana plants (cv. Pisang Awak) from farmer-managed fields in Uganda, Tanzania, and Rwanda. From each plant, a $30-\mathrm{cm}$ portion of infected pseudostem was removed and transported to the laboratory in a polythene bag. The two outermost sheaths on the pseudostem were peeled off and discarded. The re- 
maining exposed surface was sterilized with $75 \%$ ethyl alcohol and dried on sterile absorbent tissue paper under a laminar flow hood. Sterilized stems were cut aseptically into two cross-section pieces and kept at a slight slant until bacterial ooze was observed (10 to $15 \mathrm{~min}$ ). Bacterial ooze was picked and directly streaked onto YPG medium and incubated at $25^{\circ} \mathrm{C}$ for 3 days. Colonies resembling Xanthomonas spp. were purified on YPG medium and maintained as described above.

Pathogenicity testing. Pathogenicity tests were performed in the Lake Victoria basin in Uganda, Africa on all isolates recovered from banana tissue. An approximately $10^{8} \mathrm{CFU} / \mathrm{ml}$ bacterial suspension $(1 \mathrm{ml})$ was injected into the stem $(5$ $\mathrm{cm}$ above the soil line) of 10 replicate 3 month-old tissue cultured banana plantlets (cv. Pisang Awak) using a sterile syringe with a 21-gauge needle per isolate. Inoculated plants were incubated in a screenhouse at ambient temperature (approxi- mately $28^{\circ} \mathrm{C}$ ) and observed for symptom development over a 28 -day period. Control plants were inoculated with sterile distilled water $(1 \mathrm{ml})$ and maintained under similar conditions. The number of wilted plants at the end of the 28-day period was recorded. To fulfill Koch's postulates, the pathogen was reisolated from all plants showing symptoms. A $5 \mathrm{~cm}$-long piece of stem was cut $5 \mathrm{~cm}$ above the point of injection and surface sterilized in $75 \%$ ethyl alcohol for $30 \mathrm{~s}$, then passed briefly through a flame. Each piece of stem was macerated in $10 \mathrm{ml}$ of $10 \mathrm{mM} \mathrm{MgSO}_{4}$ buffer. A 100 - $\mu$ l volume of the resulting suspension was spread plated onto YPG and incubated at $25^{\circ} \mathrm{C}$ for 3 days. Recovery of bacterial colonies similar to those of the inoculated isolate was taken as confirmation of Koch's postulates.

DNA extraction. Genomic DNA was extracted from banana tissue, bacterial ooze, and pure cultures grown on either YDC or YPG media using a cetyl- trimethylammonium bromide solution as described previously (45). Purified DNA was diluted 1:10 (Africa tests) or to 50 $\mathrm{ng} / \mu \mathrm{l}$ (United States tests) for use in PCR.

DNA fingerprinting. $X$. campestris pv. musacearum strains were fingerprinted using the enterobacterial repetitive intergenic consensus (ERIC) primers ERIC1R and ERIC2 (12). ERIC-PCR was performed using the conditions described by Louws et al. (29) in a PTC-100 thermocycler (MJ Research Inc., Waltham, MA) with whole-cell template. Whole-cell template was prepared by suspending one loopful of bacteria from a 48-h YDC agar plate into $200 \mu \mathrm{l}$ of sterile distilled water Suspensions were incubated at $-20^{\circ} \mathrm{C}$ until completely frozen (at least $2 \mathrm{~h}$ ) and thawed prior to use. Amplified PCR products (10 $\mu \mathrm{l})$ were separated by horizontal gel electrophoresis in $1.5 \%$ agarose gels at $12{ }^{\circ} \mathrm{C}$ in $1 \times$ Tris-acetate-EDTA buffer $(40 \mathrm{mM}$ Tris, $20 \mathrm{mM}$ acetic acid, $1 \mathrm{mM}$ EDTA, pH 8.3) for $7.5 \mathrm{~h}$ at $50 \mathrm{~V}$. Gels were stained in di-

Table 1. Strains and their host and source that were used in this study

\begin{tabular}{|c|c|c|}
\hline Pathogen, strain ${ }^{\mathrm{a}}$ & Host & Source \\
\hline \multicolumn{3}{|l|}{ Xanthomonas campestris pv. musacearum } \\
\hline R11-06, R12-06, R13-06, R14-06, R15-06, R17-06, R18-06 & Banana & This study, Rwanda \\
\hline T1-06, T2-06, Т3-06, Т4-06, Т5-06, T6-06, Т7-06, Т8-06, T9-06, Т10-06 & Banana & This study, Tanzania \\
\hline $\begin{array}{l}\text { UG1-06, UG2-06, UG3-06, UG4-06, UG6-06, UG7-06, UG8-06, UG9-06, UG10-06, UG11-06, UG12-06, } \\
\text { UG13-06, UG14-06, UG15-06, UG17-06, UG18-06, UG3-019, UG21-06, UG22-06, UG23-06, UG24-06, } \\
\text { UG25-06, UG27-06, UG28-06, UG29-06, UG30-06, UG31-06, UG32-06, UG33-06, UG34-06, UG35-06, } \\
\text { UG36-06 }\end{array}$ & Banana & This study, Uganda \\
\hline \multicolumn{3}{|l|}{$X$. campestris pv. vesicatoria } \\
\hline $110 \mathrm{c}, 17 \mathrm{~b}$ & Pepper & S. Miller \\
\hline $761,767,794 a, 788,791,1220$ & Tomato & S. Miller \\
\hline \multicolumn{3}{|l|}{$X$. campestris pv. vitians } \\
\hline $700 \mathrm{a}, 701 \mathrm{a}$ & Lettuce & S. Miller \\
\hline \multicolumn{3}{|l|}{ X. campestris pv. campestris } \\
\hline A4956, A4964, A4953, A4947, A4962 & Cabbage & A. Alvarez \\
\hline $\mathrm{Cb} 8$ & Cabbage & G. Tusiime \\
\hline $\operatorname{Br} 5$ & Broccoli & G. Tusiime \\
\hline NCPPB 528 & Brussels sprouts & G. Tusiime \\
\hline \multicolumn{3}{|l|}{ X. campestris pv. amoracea } \\
\hline $704 \mathrm{~b}$ & Radish & S. Miller \\
\hline 756c, HW9, 704e & Radish & S. Kamoun \\
\hline \multicolumn{3}{|l|}{ X. campestris pv. raphani } \\
\hline DC91-1 & Tomato & D. Cuppels \\
\hline $737,738,741$ & Tomato & S. Miller \\
\hline \multicolumn{3}{|l|}{ X. axonopodis pv. vasculorum } \\
\hline NCPPB 702, NCPPB 796, NCPPB 1326, MA2771, XV24, W4, UVZ011 & Sugarcane & G. Tusiime, C. Webb \\
\hline NCPPB 206 & Maize & G. Tusiime, C. Webb \\
\hline NCPPB 892, PDDCC327 & Tiger grass & G. Tusiime, C. Webb \\
\hline \multicolumn{3}{|l|}{ X. vasicola pv. holcicola } \\
\hline NCPPB 2417, Z1, Z5, SAS211, TX1, Mexico1A, NCPPB 1241 & Sorghum & G. Tusiime, C. Webb \\
\hline ATCC 13461 & Holcus & C. Webb \\
\hline \multicolumn{3}{|l|}{ X. gardneri } \\
\hline XCGA2, XV444, XV451, DC00T20A, DC03T4 & Tomato & D. Cuppels \\
\hline \multicolumn{3}{|l|}{ X. oryzae pv. oryzae } \\
\hline $\mathrm{J} 17, \mathrm{~J} 12, \mathrm{~J} 22, \mathrm{~J} 6, \mathrm{R} 6$ & Rice & G. Wang \\
\hline \multicolumn{3}{|l|}{ Clavibacter michiganensis subsp. michiganensis } \\
\hline C290, A226 & Tomato & D. Francis \\
\hline \multicolumn{3}{|l|}{ Pseudomonas syringae pv. tomato } \\
\hline DC3000 & Tomato & D. Cuppels \\
\hline \multicolumn{3}{|l|}{ P. syringae pv. maculicola } \\
\hline $88-10$ & Tomato & D. Cuppels \\
\hline \multicolumn{3}{|l|}{ P. syringae pv. syringae } \\
\hline SM22-01 & Tomato & S. Miller \\
\hline \multicolumn{3}{|l|}{ Ralstonia solanacearum race 1 , biovar 3} \\
\hline NO65-01 & Eggplant & S. Miller \\
\hline
\end{tabular}

${ }^{a}$ Xanthomonas nomenclature is according to the International Society of Plant Pathology (59) or the International Journal of Systematic and Evolutionary Microbiology. 
lute ethidium bromide ( $2 \mu \mathrm{g} / \mathrm{ml})$, and DNA was visualized under UV light and photographed using the Kodak Electrophoresis Documentation and Analysis System 290 (Eastman Kodak Company, New Haven, CT).

X. campestris-specific PCR. The PCR primers RST65 (5'GTCGTCGTTACG GCAAGGTGGTCG3') and RST69 (5'TCG CCCAGCGTCATCAGGCCATC3') generated from conserved sequences in the $h r p B$ operon of the hrp gene cluster from $X$. campestris pv. vesicatoria group $\mathrm{A}, \mathrm{B}, \mathrm{C}$, and D strains (35) were used to amplify all the strains listed in Table 1. Each reaction contained $1 \mu \mathrm{l}$ of whole-cell template (whole-cell preparation described above) or purified genomic DNA and $24 \mu \mathrm{l}$ of master mix $(1.25 \mu \mathrm{l}$ of each $10 \mu \mathrm{M}$ primer, $12.5 \mu \mathrm{l}$ of GoTaq Green Master Mix [GoTaq DNA polymerase at 100 units $/ \mathrm{ml}, 400$ $\mu \mathrm{M} \mathrm{dNTP}$, and $3 \mathrm{mM} \mathrm{MgCl}_{2}$; Promega Corporation, Madison, WI] and $10 \mu \mathrm{l}$ of sterile milliQ water). PCR was performed in a PTC-100 thermocycler (MJ Research Inc.) using the following program: $5 \mathrm{~min}$ at $95^{\circ} \mathrm{C} ; 30$ cycles of $30 \mathrm{~s}$ at $95^{\circ} \mathrm{C}, 30 \mathrm{~s}$ at $63^{\circ} \mathrm{C}$, and $40 \mathrm{~s}$ at $72^{\circ} \mathrm{C}$; and then a 5 -min final extension at $72^{\circ} \mathrm{C}$. Water was used as a negative control for all amplifications. PCR products $(10 \mu \mathrm{l})$ were separated by horizontal gel electrophoresis in $1.5 \%$ agarose in $0.5 \times$ Tris-borate-EDTA (TBE) buffer at $50 \mathrm{~V}$ for $60 \mathrm{~min}$. Gels were stained and DNA visualized as described above.

Nucleotide sequencing. The 422-bp amplicon from $X$. campestris strains $110 \mathrm{C}$, 791, and 1220 and $X$. campestris pv. musacearum strains T3-06, T6-06, R17-06, and R18-06, produced by PCR with the RST65 and RST69 primers, were gel puri- fied using the Qiagen QIAquick spin kit (Qiagen Inc, Chatsworth, CA) according to the manufacturer's instructions. Direct sequencing in both the forward and reverse directions of gel-purified amplification products was performed at the PlantMicrobe Genomics Facility, The Ohio State University, Columbus, using an automated 3730 DNA Analyzer (Applied Biosystems, Inc.). Base calling and sequence quality were determined for both strands of the sequences generated using Mac Phred-Mac Phrap software $(17,18)$. The software Sequencher (Sequencher 3.0; Gene Codes Corporation, Ann Arbor, Michigan) was used to assemble, edit, trim, and generate high-quality consensus sequences. Sequence alignments of the consensus sequences were performed and similarity values were calculated with the ClustalW algorithm in Mac Vector (Mac vector 6.1; Oxford Molecular Ltd., Beaverton, OR) using default settings.

BXW primer design and PCR. $X$. campestris pv. musacearum-specific oligonucleotide primers were designed from regions of the RST65/69 consensus sequences that had minimal variability within each of the two groups (X. campestris and $X$. campestris pv. musacearum strains) but a high degree of variability between the two groups. A similarity matrix was calculated using MEGA 3.1 with default settings to determine the number of nucleotide differences within and between the two groups (23). Primers were initially tested using Amplify 3.1X software (16). The $X$. campestris pv. musacearumspecific PCR primers (BXW-1: 5'GTC GTTGGCACCATGCTCA3' and BXW-3: 5'TCCGACCGATACGGCT3') were used in PCR with whole-cell preparations of all the strains listed in Table 1, bacterial ooze from infected tissue, and genomic DNA (1:10) purified from bacterial ooze or infected tissue. Each reaction contained $1 \mu \mathrm{l}$ of template and $24 \mu \mathrm{l}$ of master mix (1.25 $\mu \mathrm{l}$ of each $10 \mu \mathrm{M}$ primer, $12.5 \mu \mathrm{l}$ of GoTaq Green Master Mix [GoTaq DNA polymerase at 100 units $/ \mathrm{ml}, 400 \mu \mathrm{M}$ dNTP, and $3 \mathrm{mM} \mathrm{MgCl}_{2}$; Promega Corporation], and $10 \mu$ of sterile milliQ water). PCR was performed in a PTC-100 thermocycler (MJ Research Inc.) using the following program: $5 \mathrm{~min}$ at $95^{\circ} \mathrm{C} ; 30$ cycles of $30 \mathrm{~s}$ at $95^{\circ} \mathrm{C}, 30 \mathrm{~s}$ at $55^{\circ} \mathrm{C}$, and $30 \mathrm{~s}$ at $72^{\circ} \mathrm{C}$; and then a 5-min final extension at $72^{\circ} \mathrm{C}$. Water was used as a negative control for all amplifications. PCR products $(10 \mu \mathrm{l})$ were separated by horizontal gel electrophoresis in $1.5 \%$ agarose in $0.5 \times \mathrm{TBE}$ buffer at 50 $\mathrm{V}$ for $60 \mathrm{~min}$. Gels were stained and DNA visualized as described above.

The sensitivity of the BXW primers using the PCR assay described above was determined using a pure culture of $X$. campestris pv. musacearum (strain R11-06). A 1-ml bacterial suspension (optical density at 600 $\mathrm{nm}=0.23)$ was prepared in sterile distilled water and diluted to $10^{-9}$ using 10 fold serial dilutions. Each dilution $(1 \mu \mathrm{l})$ was used as template in PCR and $100 \mu \mathrm{l}$ was plated onto YDC in triplicate. The plates were incubated for $72 \mathrm{~h}$ at $28^{\circ} \mathrm{C}$ and counted, and the $\mathrm{CFU} / \mathrm{ml}$ was calculated.

\section{RESULTS}

Isolation and pathogenicity of $X$. campestris pv. musacearum strains. Fifty isolates were collected and purified from naturally infected banana plants from Uganda, Tanzania, and Rwanda. All of the strains caused wilt within 28 days when inoculated into cv. Pisang Awak plantlets

Table 2. Polymerase chain reaction (PCR) amplification results using Xanthomonas campestris-specific and X. campestris pv. musacearum-specific primers

\begin{tabular}{|c|c|c|c|}
\hline Pathogen & No. of strains evaluated & X. campestris-specific primers ${ }^{\mathrm{a}}$ & BXW-specific primers ${ }^{b}$ \\
\hline X. campestris pv. musacearum & 50 & $+(2)$ & + \\
\hline$X$. campestris pv. vesicatoria & 8 & + & - \\
\hline X. campestris pv. vitians & 2 & + & - \\
\hline X. campestris pv. campestris & 8 & + & - \\
\hline X. campestris pv. amoracea & 4 & + & - \\
\hline X. campestris pv. raphani & 4 & + & - \\
\hline X. axonopodis pv. vasculorum & 10 & & \\
\hline NCPPB 796, NCPPB 892, MA2771 & $\ldots$ & + & - \\
\hline PDDCC327, XV24 & $\ldots$ & + & - \\
\hline W4, NCPPB 702 & $\ldots$ & + & + \\
\hline UVZ011, NCPPB 206, NCPPB 1326 & $\ldots$ & $+(2)$ & + \\
\hline X. vasicola pv. holcicola & 8 & & \\
\hline ATCC 13461, TX1 & $\ldots$ & - & - \\
\hline SAS211, NCPPB 1241 & $\ldots$ & + & - \\
\hline $\mathrm{Z5}$ & $\ldots$ & + & + \\
\hline Z1, NCPPB 2417, Mexico1A & $\ldots$ & $+(2)$ & + \\
\hline X. oryzae pv. oryzae & 5 & + & - \\
\hline$X$. gardneri & 5 & + & - \\
\hline Clavibacter michiganensis subsp. michiganensis & 2 & - & - \\
\hline Pseudomonas syringae pv. tomato & 1 & - & - \\
\hline P. syringae pv. maculicola & 1 & - & - \\
\hline$P$. syringae pv. syringae & 1 & - & - \\
\hline Ralstonia solanacearum race 1 , biovar 3 & 1 & - & - \\
\hline
\end{tabular}

a RST65 and RST69 (35); + indicates that a single amplicon of 287 bp (X. campestris-specific PCR) or 214 bp (banana Xanthomonas wilt [BXW]-specific PCR) was produced; +(2) indicates that two amplicons (422 and $287 \mathrm{bp}$ ) were produced; and - indicates that no amplicon was produced.

b BXW-1 and BXW-3 (this study). 
and were successfully recovered from the plantlets, thereby fulfilling Koch's postulates. None of the noninoculated control

X. campestris-specific-PCR. All but two (ATCC 13461 and TX1, identified as plantlets developed symptoms.

X. vasicola pv. holcicola) of the Xanthomonas strains tested produced the expected 422-bp product when amplified with the RST65 and RST69 PCR primers (RST primers). In addition to the 422-bp product, all of the $X$. campestris pv. musacea-
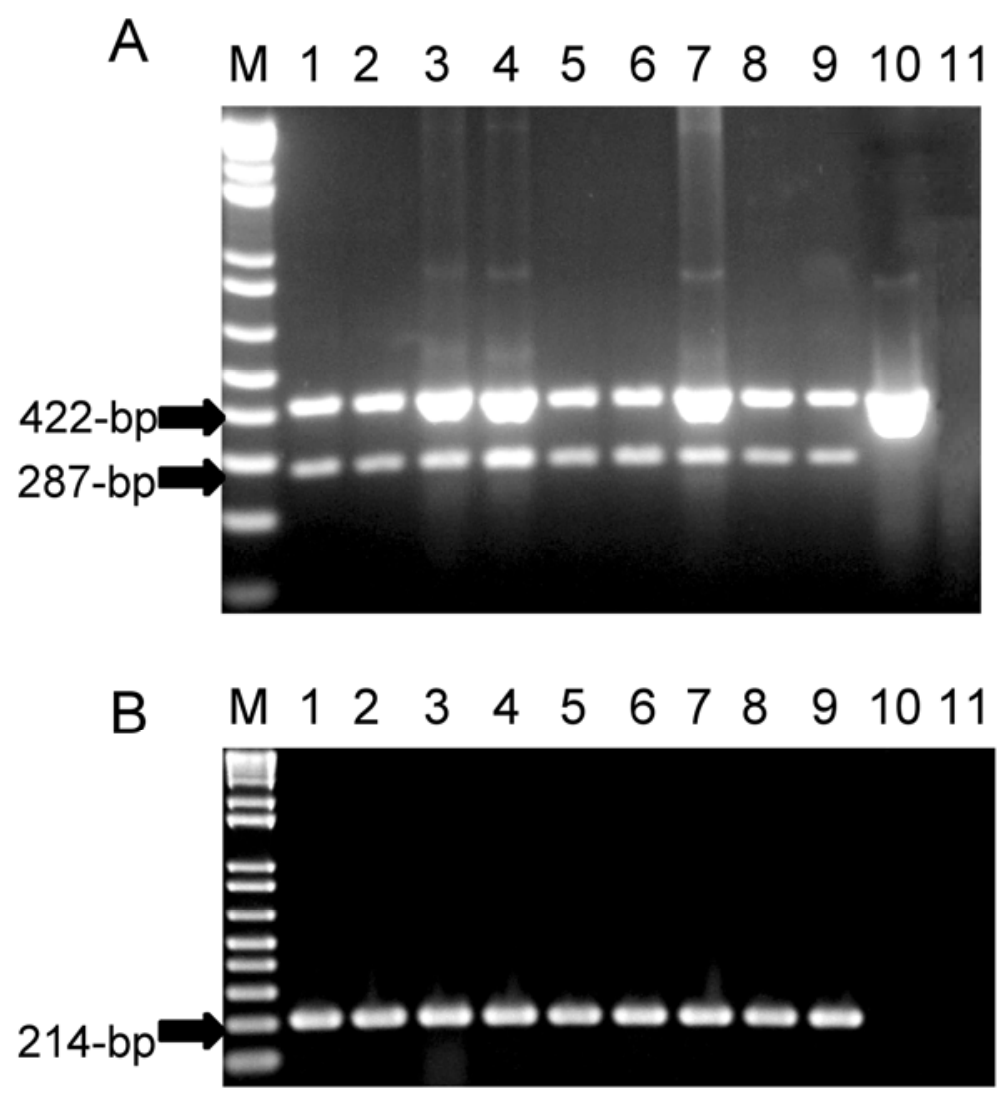

Fig. 1. Polymerase chain reaction (PCR) amplification of representative strains of Xanthomonas vasicola pv. musacearum from Uganda (UG), Tanzania (T), and Rwanda (R) with A, RST primers and B, banana Xanthomonas wilt primers. PCR was performed with whole-cell template as described in the Materials and Methods. Lane M, 1-kb plus ladder (Invitrogen Corp., Carlsbad, CA); lane 1, UG2-06; lane 2, UG15-06; lane 3, UG34-06; lane 4, T3-06; lane 5, T5-06; lane 6, T8-06; lane 7, R11-06; lane 8, R15-06; lane 9, R18-06, lane 10, X. campestris pv. vesicatoria 791; lane 11, Pseudomonas syringae pv. tomato DC3000.

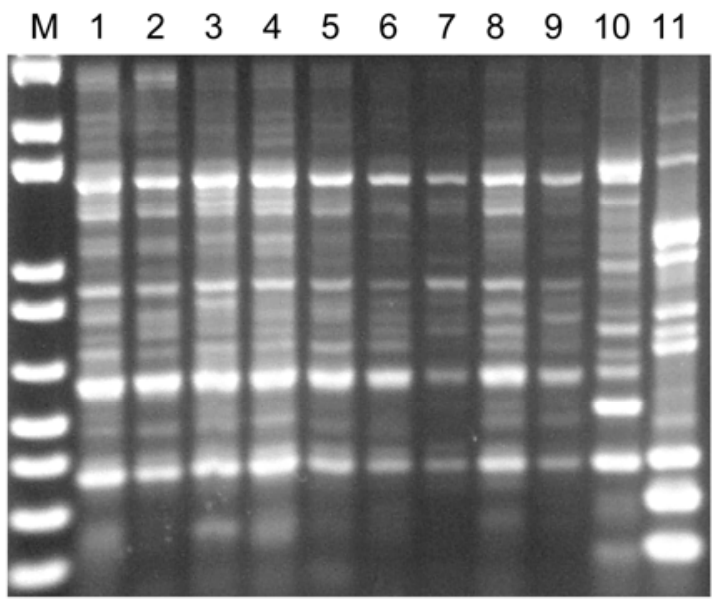

Fig. 2. Repetitive sequence-based polymerase chain reaction fingerprinting patterns using the enterobacterial repetitive intergenic consensus (ERIC) primers ERIC1R and ERIC2 generated for representative strains of Xanthomonas campestris pv. musacearum from Uganda (UG), Tanzania (T), and Rwanda (R) using ERIC primers. Lane M, 1-kb plus ladder (Invitrogen Corp., Carlsbad, CA); lane 1, UG2-06; lane 2, UG15-06; lane 3, UG34-06; lane 4, T3-06; lane 5, T5-06; lane 6, T8-06; lane 7, R1106; lane 8, R15-06; lane 9, R18-06, lane 10, X. campestris pv. vesicatoria 791; lane 11, Pseudomonas syringae pv. tomato DC3000. rum strains, 3 of the $10 X$. campestris pv. vasculorum strains, and 3 of the $8 X$. vasicola pv. holcicola strains produced a smaller, 287-bp product (Table 2). No amplicons were produced for the Pseudomonas, Clavibacter, or Ralstonia strains or the water controls (Table 2). PCR amplification of representative strains of $X$. campestris pv. musacearum from Uganda, Tanzania, and Rwanda with RST primers is shown in Figure 1.

BXW primer design and PCR. To develop specific primers for the $X$. campestris pv. musacearum strains, the 422-bp amplicon generated from the RST primers was sequenced for three selected $X$ campestris strains (110C, 791, and 1220) and four selected strains of $X$. campestris pv. musacearum (T3-06, T6-06, R17-06, and R18-06). After editing and trimming of the sequenced products, a 399nucleotide (nt), high-quality consensus sequence was generated. Aligned sequences were examined to determine regions of variability between the groups of strains generating one ( $X$. campestris group) or two (X. campestris pv. musacearum group) amplicons when amplified by PCR with the RST primers (Table 2). The two groups differed by an average of 48.7 nt. Within the $X$. campestris and $X$. campestris pv. musacearum groups, there were, on average, 38.3 and 0 nt differences, respectively. In the 200- to 295-nt region of the 399-nt sequence, there were, on average, $19 \mathrm{nt}$ differences that accounted for $39 \%(19 / 48.7)$ of the total variability between the two groups. The forward primer (BXW-1) for the $X$. campestris pv. musacearum PCR was developed $6 \mathrm{bp}$ upstream from the $5^{\prime}$ end of the RST65 primer sequence and the reverse primer (BXW-3) was developed within the variable 200- to 295-nt region of the sequences; specifically from nucleotides 210 to 220 . All of the $X$. campestris pv. musacearum strains from this study produced a single, 214-bp product by PCR with primers BXW-1 and BXW-3 (Table 2; Fig. 1). In addition to these strains, $50 \%$ of all of the $X$. campestris vasculorum and all of the $X$. campestris holcicola strains tested produced a 214-bp product with the BXW primers (Table 2). No amplicon was produced for any of the other Xanthomonas strains or the Pseudomonas, Clavibacter, or Ralstonia strains tested (Table 2), or the water controls (data not shown). A 214-bp product was generated regardless of the type of template (genomic DNA from symptomatic tissue, genomic DNA from bacterial ooze, and bacterial ooze from BXW-diseased plants) used for PCR. No PCR products were amplified from genomic DNA from healthy tissue (data not shown). The detection limit for whole $X$. campestris pv. musacearum (R11-06) cells from pure culture used directly as template in PCR with the BXW primers was $10^{4}$ to $10^{5} \mathrm{CFU} / \mathrm{ml}$ (data not shown). 
ERIC-PCR genomic fingerprinting analysis of $X$. campestris pv. musacearum strains. ERIC-PCR generated complex fingerprinting patterns consisting of 11 or more distinct bands ranging in size from $0.35 \mathrm{~kb}$ to approximately $3 \mathrm{~kb}$. Fingerprint patterns, under our reaction conditions, from $X$. campestris pv. musacearum strains isolated from Uganda, Rwanda, and Tanzania were identical (Fig. 2), indicating that the strains causing disease in these countries are clonal. None of the other Xanthomonas strains, including the vasculorum and holcicola pathovar strains that produced a 214-bp product with the BXW primers, were identical to the musacearum strains (data not shown). The vasculorum and holcicola strains (Table 1) had two to three bands and one to two bands in common with the musacearum strains, respectively (data not shown).

\section{DISCUSSION}

We developed a rapid whole-cell PCR assay using primers specific to a region of the $h r p B$ gene cluster to detect $X$. campestris pv. musacearum. The use of these primers with PCR will allow for the early detection of this pathogen, which is critical due to its rapid and uncontrolled spread on symptomatic and asymptomatic crop material and through insect vectors throughout Africa. The presence of an additional, apparently unique amplicon in PCR assays using the primers (RST65 and RST69) designed to be specific to strains of $X$. campestris pv. vesicatoria isolated from pepper and tomato (35) suggested that a specific primer for $X$. campestris pv. musacearum could be developed from the same region of the $h r p B$ gene from which the RST primers were developed. Sequence analysis of the 422-bp fragment revealed that the RST reverse primer (RST69) had two binding sites in strains of $X$. campestris pv. musacearum. Using this sequence information, a new reverse primer, internal to the smaller 287-bp product, was designed. In addition, the forward RST primer (RST65) was slightly modified to increase its specificity. The new primers (BXW-1 and $\mathrm{BXW}-3$ ) were then evaluated for cross-reactivity to other phytopathogenic Xanthomonas spp. and pathovars. The BXW1 and BXW3 primers cross-reacted with some but not all of the strains of X. vasicola pv. holcicola and $X$. axonopodis pv. vasculorum tested in this study. Interestingly, three of the X. vasicola pv. holcicola strains (Z1, NCPPB 2417, and Mexico1A) and three of the $X$. axonopodis pv. vasculorum strains (UVZ011, NCPPB 206, and NCPPB 1326) that cross-reacted with the $\mathrm{BXW}$ primers produced two amplicons with the RST primers. Based on these findings, it was hypothesized that these strains may be very similar to $X$. campestris pv. musacearum. Although ERIC fingerprint patterns for these strains had little similarity (ap- proximately 9 to $27 \%$ similarity) to $X$. campestris pv. musacearum strains, recent taxonomic studies using fatty acid profiles, repetitive sequence-based PCR, and sequencing of gyrB showed that $X$. campestris pv. musacearum is very similar to $X$. vasicola pv. holcicola isolated from sugarcane and maize from Africa (2) and sorghum from New Zealand (28). Aritua et al. (2) also showed that $X$. axonopodis pv. vasculorum strains isolated from sugarcane and maize were very similar to strains of $X$. campestris pv. musacearum. However, a more recent study by Parkinson et al. (38) showed that the $\operatorname{gyr} B$ sequence of $X$. axonopodis pv. vasculorum was dissimilar to that of a strain of $X$. campestris pv. musacearum from Ethiopia. Aritua et al. (3) proposed reclassification of $X$. campestris pv. musacearum to $X$. vasicola but this reclassification has not yet been accepted. Based on these two studies, it is not unexpected that our BXW primers crossreacted with $X$. vasicola pv. holcicola. Although the BXW primers can crossreact with both $X$. vasicola pv. holcicola and $X$. axonopodis pv. vasculorum, neither of these pathogens has been shown to cause disease in banana using artificial inoculations (2). In addition, to the best of our knowledge, there have been no reports of these two pathogens being isolated from diseased banana trees or enset found in the field; therefore, the practical utility of this assay is not likely to be compromised on the target crops. Furthermore, the $X$. campestris pv. musacearum strains from Uganda, Tanzania, Rwanda, and Burundi (M. L. Lewis Ivey and S. A. Miller, unpublished) were clonal, indicating that false negatives are unlikely due to the lack of strain variation. Finally, any nonpathogenic Xanthomonas spp. that may be present on asymptomatic or symptomatic tissue will not be detected because hrp gene sequences are not present in their genomes. The BXW primers target the $h r p B$ gene sequence of the $h r p$ gene cluster. Among pathovars of $X$. campestris, hrp sequences are both functionally and physically similar, and finding a uniquely conserved portion can be difficult. Once the classification of $X$. campestris pv. musacearum is resolved, it may be worthwhile to investigate a more specific region in the $h r p$ gene cluster sequence for primer development. Currently, this assay is being used in Africa to diagnose BXW and has been especially useful because the disease is moving into new areas, where symptoms are unfamiliar. The widespread availability of this assay in Africa will serve as a critical tool to help monitor the spread of this damaging plant disease, allowing appropriate management techniques to be initiated.

\section{ACKNOWLEDGMENTS}

This project was made possible by the United States Agency for International Development (USAID) and the generous support of the American people through USAID Cooperative Agreement No.
EPPA-00-04-000 16-00, and by state and federal funds appropriated to the Ohio Agricultural Research and Development Center, The Ohio State University. We thank C. Webb, D. Cuppels, S. Kamoun, A. Alvarez, D. Francis, and G.-L. Wang for providing us with isolates used in this study; and B. McSpadden Gardener and G. Rajashekara for critical reviews of this manuscript.

\section{LITERATURE CITED}

1. Alfano, J. R., and Collmer, A. 1997. The type III (Hrp) secretion pathway of plant pathogenic bacteria: trafficking harpins, Avr proteins, and death. J. Bacteriol. 179:5655-5662.

2. Aritua , V., Nanyonjo, A., Kumakech, F., and Tushemereirwe, W. 2008. Rep-PCR reveals a high genetic homogeneity among Ugandan isolates of Xanthomonas campestris pv. musacearum. Afr. J. Biotechnol. 6:179-183.

3. Aritua V., Parkinson, N., Thwaites, R., Heeney, J. V., Jones, D. R., Tushemereirwe, W., Crozier, J., Reeder, R., Stead, D. E., and Smith, J. 2008. Characterization of the Xanthomonas sp. causing bacterial wilt of enset and banana and its proposed reclassification as a strain of $X$. vasicola. Plant Pathol. 57:170177.

4. Bafana, B. 2008. Trade-East Africa: Going Bananas to Fight Poverty and Hunger. IPS Inter Press Service News Agency (IPS). http:// ipsnews.net/news.asp?idnews $=44210$. Accessed October 2008.

5. Bereswill, S., Pahl, A., Bellemann, P., Zeller, W., and Geider, K. 1992. Sensitive and species-specific detection of Erwinia amylovora by polymerase chain reaction analysis. Appl. Environ. Microbiol. 58:3522-3526.

6. Berg, T., Tesoriero, L., and Hailstones, D. L. 2005. PCR-based detection of Xanthomonas campestris pathovars in Brassica seed. Plant Pathol. 54:416-427.

7. Biruma, M., Pillay, M., Tripathi, L., Blomme, G., Abele, S., Mwangi, M., Bandyopadhyay, R., Muchunguzi, P., Kassim, S., Nyine, M., Turyagyenda, L., and Eden-Green, S. 2007. Banana Xanthomonas wilt: a review of the disease, management strategies and future research directions. Afr. J. Biotechnol. 6:953962.

8. Chen, J., Groves, R., Civerolo, E. L., Viveros, M., Freeman, M., and Zheng, Y. 2005. Two $X y$ lella fastidiosa genotypes associated with almond leaf scorch disease on the same location in California. Phytopathology 95:708-714.

9. Cubero, J., and Graham, J. H. 2002. Genetic relationship among world wide strains of Xanthomonas causing canker in citrus species and design of new primers for their identification by PCR. Appl. Environ. Microbiol. 68:12571264.

10. Cuppels, D. A., Louws, F. J., and Ainsworth, T. 2006. Development and evaluation of PCRbased diagnostic assays for the bacterial speck and bacterial spot pathogens of tomato. Plant Dis. 90:451-458.

11. Cuppels, D. A., Moore, R. A., and Morris, V. L. 1990. Construction and use of a nonradioactive DNA hybridization probe for detection of Pseudomonas syringae pv. tomato on tomato plants. Appl. Environ. Microbiol. 56:17431749 .

12. de Bruijn, F. J. 1992. Use of repetitive extragenic palindromic and enterobacterial repetitive intergenic consensus sequences and the polymerase chain reaction to fingerprint the genomes of Rhizobium meliloti isolates and other soil bacteria. Appl. Environ. Microbiol. 58:2180-2187.

13. DeParasis, J., and Roth, D. A. 1990. Nucleic acid probes for identification of phytobacteria: identification of genus-specific 16S rRNA sequences. Phytopathology 80:618-621.

14. Dreier, J., Bermpohl, A., and Eichenlaub, R. 1995. Southern hybridization and PCR for 
specific detection of phytopathogenic Clavibacter michiganensis subsp. michiganensis. Phytopathology 85:508-512.

15. Dye, D. W., Bradbury, J. F., Goto, M., Hayward, A. C., Lelliot, R. A., and Schroth, M. N. 1980. International standards for naming pathovars of phytopathogenic bacteria: a list of pathovars names and pathotype strains. Rev. Plant Pathol. 59:153-168.

16. Engels, B. 2005. Amplify 3.1X. University of Wisconsin. http://engels.genetics.wisc.edu/ amplify/. Accessed September 2006.

17. Ewing, B., and Green, P. 1998. Base-calling of automated sequencer traces using phred. II. Error probabilities. Genome Res. 8:186-94.

18. Ewing, B., Hillier, L., Wendl, M. C., and Green, P. 1998. Base-calling of automated sequencer traces using phred. I. Accuracy assessment. Genome Res. 8:175-85.

19. Food and Agriculture Organization of The United Nations. 2005. Banana Statistics, 2005. http://faostat.fao.org/site/339/default.aspx. Accessed January 2005.

20. Hartung, J. S., Daniel, J. F., and Pruvost, O. P. 1993. Detection of Xanthomonas campestris pv. citri by the polymerase chain reaction method. Appl. Environ. Microbiol. 59:11431148.

21. Hauben, L., Vauterin, L., Swings, J., and Moore, R. B. 1997. Comparison of $16 \mathrm{~S}$ ribosomal DNA sequences of all Xanthomonas species. Int. J. Syst. Bacteriol. 47:328-335.

22. Kerkoud, M., Manceau, C., and Paulin, J. P. 2002. Rapid diagnosis of Pseudomonas syringae pv. papulans, the causal agent of blister spot of apple, by polymerase chain reaction using specifically designed $h r p L$ gene primers. Phytopathology 92:1077-1083.

23. Kumar, S., Tamura, K., and Nei, M. 2004. MEGA3: Integrated software for molecular evolutionary genetics analysis and sequence alignment. Brief. Bioinform. 5:150-163.

24. Leite, R P, Jr., Jones, J. B., Somodi, G. C., Minsavage, G. V., and Stall, R. E. 1995. Detection of Xanthomonas campestris pv. vesicatoria associated with pepper and tomato seed by DNA amplification. Plant Dis. 79:917-922.

25. Leite, R P, Jr., Minsavage, G. V., Bonas, U., and Stall, R. E. 1994. Detection and identification of phytopathogenic Xanthomonas strains by amplification of DNA sequences related to the hrp genes of Xanthomonas campestris pv. vesicatoria. Appl. Environ. Microbiol. 60:10681077.

26. Lelliot, R. A., and Stead, D. E. 1987. Methods for the Diagnosis of Bacterial Diseases of Plants. Blackwell Scientific Publication, Oxford.

27. Li, X., and De Boer, S. H. 1995. Selection of polymerase chain reaction primers from an RNA intergenic spacer region for specific detection of Clavibacter michiganensis subsp. sepedonicus. Phytopathology 85:837-842.

28. Lindgren, P. B., Peet, R. C., and Panopoulos, N. J. 1986. Gene cluster of Pseudomonas syringae pv. "phaseolicola" controls pathogenicity of bean plants and hypersensitivity on nonhost plants. J. Bacteriol. 168:512-522.

29. Louws, F. J., Fulbright, D. W., and de Bruijn, F. J. 1994. Specific genomic fingerprints of phytopathogenic Xanthomonas and Pseudomonas pathovars and strains generated with repetitive sequences and PCR. Appl. Environ. Microbiol. 60:2286-2295.

30. Mavrodieva, V., Levy, L., and Gabriel, D. W. 2004. Improved sampling methods for realtime polymerase chain reaction diagnosis of citrus canker from field samples. Phytopathology 94:61-68.

31. Mbaka, J., Ndungu, V., and Mwangi, M. 2007. Outbreak of Xanthomonas wilt (Xanthomonas campestris pv. musacearum) on banana in Kenya. Pages 58-59 in: Program and Abstracts of ISHS/ProMusa Symposium: Recent Advances in Banana Crop Protection for Sustain- able Production and Improved Livelihoods. Greenway Woods Resort, White River, South Africa.

32. Mgenzi, S. R. B, Eden-Green S., and Peacock, J. 2006. Overview of banana Xanthomonas wilt in Tanzania. In: Proc. 4th Int. Bacterial Wilt Symp. Central Science Laboratory, York, UK.

33. Ndungo, V., Bakelana, K., Eden-Green, S., and Blomme, G. 2005. An outbreak of banana Xanthomonas wilt in the Democratic Republic of Congo. Infomusa 13:43-44.

34. Ndungo, V., Eden-Green, S., Blomme, G., Crozier, J., and Smith, J. J. 2006. Presence of banana Xanthomonas wilt (Xanthomonas campestris pv. musacearum) in the Democratic Republic of Congo (DRC). Plant Pathol. 55:294.

35. Obradovic, A., Mavridis, A., Rudolph, K., Janse, J. D, Arsenijevic, M., Jones, J. B, Minsavage, G. V., and Wang, J. 2004. Characterization and PCR-based typing of Xanthomonas campestris pv. vesicatoria from peppers and tomatoes in Serbia. Eur. J. Plant Pathol. 11:285-292.

36. Opina, N, Tavner, F., Hollway, G., Wang, J. F., Li, T. H., Maghirang, R., Fegan, M., Hayward, A.C., Krishnapillai, V., Hong, W. F., Holloway, B. W., and Timmins, J. 1997. A novel method for development of species and strain-specific DNA probes and PCR primers for identifying Burkholderia solanacearum (formerly Pseudomonas solanacearum). Asia Pac. J. Mol. Biol. Biotechnol. 5:19-30.

37. Park, Y. J., Lee, B. M., Ho-Hahn, J., Lee, G. B., and Park. D. S. 2004. Sensitive and specific detection of Xanthomonas campestris pv. campestris by PCR using species-specific primers based on $h r p F$ gene sequences. Microbiol. Res. 159:419-423.

38. Parkinson, N., Cowie, C., Heeney, J., and Stead, D. 2009. Phylogenetic structure of Xanthomonas determined by comparison of $g y r B$ sequences. Int. J. Syst. Evol. Microbiol. 59:264-274.

39. Pooler, M. R., and Hartung, S. 1995. Specific PCR detection and identification of Xylella fastidiosa strains causing citrus variegated chlorosis. Curr. Microbiol. 31:377-381.

40. Poussier, S., Prior, P., Luisetti, J., Hayward, C., and Fegan, M. 2000. Partial sequencing of the $h r p B$ and endogluconase genes confirms and expands the known diversity within the Ralstonia solanacearum species complex. Syst. Appl. Microbiol. 23:479-486.

41. Prosen, D., Hatziloukas, E., Schaad, N. W., and Panopoulos, N. J. 1993. Specific detection of Pseudomonas syringae pv. phaseolicola DNA in bean seed by polymerase chain reaction-based amplification of a phaseolotoxin gene region. Phytopathology 83:965-970.

42. Reeder, R. H., Muhinyuza, J. B., Opolot, O., Aritua, V., Crozier, J., and Smith, J. 2008. Presence of banana bacterial wilt (Xanthomonas campestris pv. musacearum) in Rwanda. Plant Pathol. 56:1038.

43. Roberts, S. J., Eden-Green, S. J., Jones, P., and Ambler, D. J. 1990. Pseudomonas syzygii sp. nov., the cause of Sumatra disease of cloves. Syst. Appl. Microbiol. 13:34-43.

44. Rodrigues, J. L. M., Silva-Stenico, M. E., Gomes, J. E., Lopes, J. R. S., and Tsai, S. M. 2003. Detection and diversity assessment of Xylella fastidiosa in field-collected plant and insect samples by using 16S rRNA and $g y r B$ sequences. Appl. Environ. Microbiol. 69:42494255 .

45. Sahin, F., Abbassi, P. A., Lewis Ivey, M. L., Zhang, J., and Miller, S. A. 2003. Diversity among strains of Xanthomonas campestris pv. vitians from lettuce. Phytopathology 93:64-70.

46. Schaad, N. W., and Stall, R. E. 1988. Xanthomonas. Pages 81-94 in: Laboratory Guide for Identification of Plant Pathogenic Bacteria, 2nd ed. N. W. Schaad, ed. APS Press, St. Paul, MN.

47. Schonfeld, J., Heuer, H., van Elas, J. D., and
Smalla, K. 2003. Specific and sensitive detection of Ralstonia solanacearum in soil on the basis of PCR amplification of $\mathrm{fliC}$ fragments. Appl. Environ. Microbiol. 69:7248-7256.

48. Seal, S. E., Jackson, L. A., Young, J. P. W., and Daniels, M. J. 1993. Differentiation of Pseudomonas solanacearum, Pseudomonas syzygii, Pseudomonas pickettii and the blood disease bacterium by partial $16 \mathrm{~S}$ rDNA sequencing: construction of oligonucleotide primers for sensitive detection by polymerase chain reaction. J. Gen. Microbiol. 139:1587-1594.

49. Smith, J. J., Jones, D. R., Karamura, E., Blomme, G., and Turyagyenda, F. L. 2008. An Analysis of the Risk from Xanthomonas campestris pv. musacearum to Banana Cultivation in Eastern, Central and Southern Africa. Biodiversity International, Montpellier, France.

50. Sousa, S. M., Cruz, L., Norskov, P., and Rasmussen, O. F. 1997. A rapid and sensitive detection of Clavibacter michiganensis subsp. michiganensis in tomato seeds by polymerase chain reaction. Seed Sci. Technol. 25:581-584.

51. Stall., R. E., and Minsavage, G. V. 1990. The use of hrp genes to identify opportunistic xanthomonads. Pages 369-374 in: Proc. 7th Int. Conf. Plant Pathol. Z. Klement, ed. Budapest.

52. Taghavi, M., Hayward, C., Sly, L. I., and Fegan, M. 1996. Analysis of the phylogenetic relationships of strains of Burkholderia solanacearum, Pseudomonas syzygii, and the blood disease bacterium on 16S rRNA gene sequences. Int. J. Syst. Bacteriol. 46:10-15.

53. Thwaites, R., Eden-Green, S. J., and Black, R. 2000. Diseases caused by bacteria. Pages 213 240 in: Diseases of Banana: Abaca and Enset, D. R. Jones, ed. CAB International, Wallingford, UK

54. Tushemereirwe, W., Kangire, A., Smith, J., Ssekiwoko, F., Nakyanzi, M., Kataama, D., Musiitwa, C., and Karyaija, R. 2003. An outbreak of bacterial wilt on banana in Uganda. Infomusa 12:6-8.

55. Tushemereirwe, W., Kangire, Ssekiwoko, F., Offord, L. C., Crozier, J., Boa, E., Rutherford, M., and Smith, J. 2004. First report of Xanthomonas campestris pv. musacearum on banana in Uganda. Plant Pathol. 53:802.

56. Willis, K., Rich, J. J., and Hrabak, E. M. 1990. hrp genes of phytopathogenic bacteria. Mol Plant-Microbe Interact. 4:132-138.

57. Yirgou, D., and Bradbury, J. F. 1968. Bacterial wilt of Enset (Ensete ventricosa) incited by Xanthomonas musacearum sp. n. Phytopathology 58:111-112.

58. Yirgou, D., and Bradbury, J. F. 1974. A note on wilt of banana caused by the Ensete wilt organism, Xanthomonas musacearum. EA Agric. For. J. 40:111-114.

59. Young, J. M., Bull, C. T., De Boer, S. H., Firrao, G., Gardan, L., Saddler, G. E., Stead, D. E., and Takikawa, Y. 2004. Names of Plant Pathogenic Bacteria Since 1995. Report of the Taxonomy of Bacterial Plant Pathogens Committee of the International Society of Plant Pathology. http://www.isppweb.org/names bacterial new2004.asp. Accessed March 2004.

60. Young, J. M., Dye, D. W., Bradbury, J. F., and Panagopoulos, C. G. 1978. A proposed nomenclature and classification for plant pathogenic bacteria. New Zealand J. Agric. Res. 21:153-177.

61. Zaccardelli, M., Campanile, F., Spasiano, A. and Merighi, M. 2007. Detection and identification of the crucifer pathogen, Xanthomonas campestris pv. campestris, by PCR amplification of the conserved Hrp/type III secretion system gene hrcC. Eur. J. Plant Pathol. 118:299-306.

62. Zaccardelli, M., Spasiano, A., Bazzi, C., and Merighi, M. 2005. Identification and in planta detection of Pseudomonas syringae pv. tomato using PCR amplification of hrpZ $\mathrm{Z}_{\mathrm{pst}}$. Eur. J. Plant Pathol. 111:85-90. 